\title{
An Investigation of Success and Failure Factors of Street Food Sector Entrepreneurs in Sylhet
}

\author{
Md. Mizanur Rahman* Fathema Rashid Saba \\ Department of Business Administration, North East University Bangladesh, Sylhet-3100, Bangladesh
}

\begin{abstract}
Street food sector is rapidly growing large informal sector in Sylhet, the holy land of Bangladesh. This study attempts to investigate the success and failure factors of entrepreneurs in the street food sector of Sylhet. The study was descriptive in nature and both qualitative and quantitative data were used. In this study, a total of 50 entrepreneurs of street food business were interviewed on the basis of convenience sampling (non-probability sampling technique) from Sylhet district. A semi-structured questionnaire was used to collect the data from the entrepreneurs with a face to face half an hour interview. Mean, mode, percentile, standard deviation were used in the data analysis. The findings of the study divulge that most of the entrepreneurs of street food sectors are young and male. The study also depicts that lack of experience of the entrepreneurs is the main failure factor of this sector. Along with this insufficient capital, a large amount of bribe, intense competition, undefined location are the key failure factors of this sector. On the other hand, the key success factors include easy formation, lower startup cost, less paperwork, fewer employees. The study also interprets that the government has less regulation in this sector, which is also a crucial success factor in this sector. For the development of this sector, the local government authority should provide some specific location for this sector. A large amount of bribe in this sector also needs to be controlled. The banks and other financial institution should provide SME loan to the entrepreneurs. The study will helps local government authority, policymakers, academician and interested persons to get a better insight into this sector.
\end{abstract}

Keywords: Street food sector, entrepreneurs, success and failures factors, Sylhet.

DOI: $10.7176 / \mathrm{EJBM} / 11-9-01$

Publication date:March $31^{\text {st }} 2019$

\section{Introduction}

Micro and small business have a great influence on the economy of a country, it is because they create job opportunity and income for the population (Parker, 1996). In Bangladesh, micro and small business have a major influence on the low-income population. The street food sector is one of the most significant and largest informal sector in the urban area of Bangladesh. This is often also called the unorganized sector in Bangladesh. A large number of the people of the country involved in the business of street food sector. This sector includes all workers and economic units which are not part of the formal economy (Muzaffar et al., 2009). The concept of street food sector was not very popular till the 1970s. Street food sector entrepreneurs have been existing since ancient time. In every civilization, the street food entrepreneurs were engaged in vending different items in street or from house to house. The main difference between shopkeepers and street food vendor is that the street food vendors have no permanent places for their trade. Wickware (1998) stated that food vending in the informal sector is often very difficult, unstable, vulnerable and illegal. The street food vendors often sell a diverse range of product which is not essential to take home for preparation rather it is ready to eat (Bhowmik, 2010; Dardano, 2003).

The street food sector is not a new business sector in Bangladesh. Yet, there a lot of issues are unknown in this sector. Most of the business in this sector has no formal setup and not government rules and regulation. This sector is still male-dominated, but the involvement of women is also increased over time. Amin (1989) stated that no formal education qualification is not essential in street food vending. The startup and maintain street food vending often requires simple skills. The works a crucial antacid for the entrepreneurs to enter in street food vending. Sometimes, their previous experience might help them to engage in business.

The sector also required a low amount of capital in the time of startup in Bangladesh. The entrepreneurs of this sector often face harassment from the government authority, they have also no specific business location. The dignity of the entrepreneurs of street food is not widely valued in Bangladesh. There are also several factors which influence the startup of street food vending. The characteristic of entrepreneurs of the street food business is still unknown (Amin, 1989). The primary objective of the study was to investigate the successes and failures factors of street food sector entrepreneurs. The secondary objectives of the study were: (i) to identify the characteristics of street food sector entrepreneurs. (ii) to recommend strategies that improve the present scenario of entrepreneurs of the street food sector.

\section{Review of the Literature}

Street food is businesses that consist of a single person or a household that has family members to help sell the products (Butale, 2001; Harvie, 2003, Ohiokpahei, 2003),). Furthermore, Bharan (2004) states that a street vendor 
is a person who offers goods and services for sale to the public without a permanently built-up structure but with a temporary static structure or mobile stall.

Like any other informal business sector, street food sales are categorized by small-scale operations, low capital costs that allow easy entry into the sector (Tinker and Fruge, 1982). It is a free sector, lacking official registration and legal acknowledgement (Mokgosi, 1997; Butale, 2001). Street food vendors operate chaotically, according to Muinde and Kuria (2005) street food vendors are haphazardly operating without monitoring what they are preparing and how they are doing it. Both females and males are actively involved in street selling activities, and most of the time street trading is the largest micro-enterprise group (Mitullah, 2003; Chukuezi, 2010). In her report, Somolekae (1992) pointed out that the majority of informal enterprises were made by women. Therefore, street sales that make up one of the major sub - sectors are characterized by: low - paid employees including the owner and three or four additional employees; expenditure is not easily distinguishable from household expenditure; operations are usually mobile or in household owners.

Most of these street food vendors function in shift structures, while some are mobile (Mokgosi, 1997; Butale, 2001). These operators do not use permanent structures; however, they operate from strategic locations including bus and train stations, markets and shopping areas, shopping districts, outside schools and hospitals, suburbs, factories, and construction sites (Draper, 1996). It appears as vendors have regular clientele in most situations (Nasinyama, 1992). In addition, typical distinguishing features of street vendors are that they keep few business records, low stock levels are maintained over a short period of time or no stock is maintained, lack of business experience, low profits, highly labour-intensive activities, large fluctuations in earnings and there is a lack of startup capital (Linden, 1993).

In Bangladesh the vendors of street food sell snack and other ready to eat food such as tea, biscuits, nuts, chicken fry, noodles, juice etc. (Muzaffar et. al., 2009; Ahsan, 2012; Alauddin, 2015). The size of the street food business is repeatedly very small and require relatively simple skill, low facilities, small capital, and few employees. The street food vendor often established their business in a busy and crowded street in any city. Several studies indicate that the street food sector has a very momentous impact on the economy of the country (Holya \& Makhoanec, 2006). This sector provides meal facilities for the middle-income people, though it is not hygienic and also it's created employment facilities for the large unemployed people in the country (Subratty et. al., 2004). The economic impact of street food vending is very high if we consider the annual sales of street food it is 67 million US dollars in Bogor in Indonesia, 2.2 billion US dollars in Malaysia. Thus street food vending plays a noteworthy role in any economy (Allain, 1988; Cohen, 1986).

Street vendors also act as economic support in buying and selling goods and services to other businesses. Jimu (2004) also adds that street selling offers viable alternatives to formal employment for subsistence living in urban areas. For the unemployed, street selling is their only means of survival, leading to the informal sector's rapid growth, mostly in larger cities. Street selling has been less investigated as it is not legitimately permitted and sellers are often harassed by government officials, particularly the unlicensed (Bhowmik, 2003; Ohiokpehai, 2003).

Street vendors create economic resources to support themselves because the efforts of urban development do not provide formal employment (Tripp, 1997). If it can cope with challenges and maintain or enhance its capabilities and assets, a livelihood is sustainable (Joseph 2011). Successful street sales as a form of diversification are generally recognized as an important strategy to reduce the challenges or vulnerability to livelihoods (Joseph, 2011). People turning to the informal sector for their livelihoods are increasing. Street sales provide jobs and income as a livelihood strategy for the urban poor, so it is a dynamic process in which people are engaged in building their livelihoods. Urban planners formulate policies in developing countries to control the operation of the informal sector, particularly street vending activities (Palmer, 2007), but some of these policies are not friendly to street vendors (Palmer, 2007; Joseph, 2011). For example, they frequently carry out inspections and demolitions, confiscate goods and sometimes remove some street vendors from where they operate (Joseph, 2011). In addition, restrictive bureaucratic regulations are some of the challenges that affect street vendors and lack of business facilities (Linden, 1993).

\section{Research Methodology}

The study conducted during the period of January 2019 to February 2019 in Sylhet metropolitan city. A total of 50 street food entrepreneurs was considered as participants in this study. The participants of the study were selected through the convenience sampling (non-probability sampling technique). The person who started the business as a vendor is considered as entrepreneurs and the main subjects of the study. The entrepreneurs of the street food sector were involved in this study with their approval and no one is coerced or forced for the data. A semistructured questionnaire was used to collect the data from the participant with a one and half hour long face to face interview. The pre-test of the questionnaire has been conducted in January 2019 on 10 entrepreneurs of the street food sector. The collected data were reviewed after collection and coded, classified and tabulated through the Statistical Package for the Social Science. 


\section{Result and Discussions}

The demographic profile of the participants will help to get an insight into the characteristics of the entrepreneurs of the street food sector. The demographic information is highlighted in Table 1.

Table 1: Information on Respondents

\begin{tabular}{llllll}
\hline Item & Freq. & \% & Item & Freq. & $\%$ \\
\hline Gender & & & Marital status & & \\
Male & 47 & 94 & Single & 13 & 26 \\
Female & 3 & 6 & Married & 37 & 74 \\
Total & 50 & 100 & Total & 50 & 100 \\
& & & & & \\
Age of respondents & & 38 & Pducation level & 25 & 50 \\
Less than 30 years & 19 & 28 & School secondary & 19 & 38 \\
31-40 years & 14 & 24 & Higher secondary & 3 & 6 \\
41-50 years & 12 & 10 & Bachelor degree & 3 & 6 \\
Above 50 years & 5 & 100 & Total & 50 & 100 \\
Total & 50 & &
\end{tabular}

Table 1 represents that majority of the participant were male (94 percent) and the rest are female (6 percent). The age of most of the respondents were 31-40 years (28 percent). A large number of respondent were aged between 41-50 years old (24 percent) and 22 percent of participants were aged between 21-30 years. Only 16 percent of participants were age less than 20 years and 10 percent were aged above 50 years. Thus, the data stated that the street food sector has a large number of young employees. The data shows that the majority of the respondent were below primary education (50 percent) and a large number of participants have a secondary degree (38 percent). The rest of them having a higher secondary level of degree (12 percent). The table also highlighted that most of the entrepreneurs were married ( 74 percent) and the rest of them are single ( 26 percent). The data also highlighted the majority of entrepreneurs established their business less than 5 years ago (66 percent) and only 6 percent established their business above 10 years ago. The rest of them established their business in the year between 6-10 years ago.

The economic profile of the participants will give us a clear view about the working hours, per day total cost and income, the importance of income to family members and alternative income source. The economic profile of the participant is presented in Table 2 .

Table 2: Economic Profile of Respondents

\begin{tabular}{|c|c|c|c|c|c|}
\hline Item & Freq. & $\%$ & Item & Freq. & $\%$ \\
\hline \multicolumn{3}{|c|}{ Working hours (hours per day) } & \multicolumn{3}{|c|}{ Proportion of family income } \\
\hline Less than 7 hours & 3 & 6 & Less than 25 percent & 1 & 2 \\
\hline 5-7 hours & 13 & 26 & $16-50$ percent & 14 & 28 \\
\hline $8-10$ hours & 19 & 38 & $51-75$ percent & 18 & 36 \\
\hline 11-12 hours & 15 & 30 & 76-100 percent & 17 & 34 \\
\hline Total & 50 & 100 & Total & 50 & 100 \\
\hline \multicolumn{3}{|c|}{ Alternative income source } & \multicolumn{3}{|l|}{ Ownership structure } \\
\hline Yes & 18 & 36 & Sole proprietorship & 47 & 94 \\
\hline No & 32 & 64 & Partnership & 3 & 6 \\
\hline Total & 50 & 100 & Total & 50 & 100 \\
\hline \multicolumn{3}{|l|}{ Total cost in a day } & \multicolumn{3}{|l|}{ Total sale in a day } \\
\hline Less than $1000 \mathrm{Tk}$. & 12 & 24 & Less than $1000 \mathrm{Tk}$. & 19 & 38 \\
\hline $1100-2000 \mathrm{Tk}$. & 14 & 28 & $1100-2000 \mathrm{Tk}$. & 24 & 48 \\
\hline 2100-3000 Tk. & 23 & 46 & $2100-3000 \mathrm{Tk}$. & 6 & 12 \\
\hline Above $3000 \mathrm{Tk}$. & 1 & 2 & Above $3000 \mathrm{Tk}$. & 1 & 2 \\
\hline Total & 50 & 100 & Total & 50 & 100 \\
\hline
\end{tabular}

It is obvious from the data that most of the participants (68 percent) working more than 8 hours per day in their business. A total of 26 percent working 5-7 hours per day and the rest of the participants (6 percent) working less than 5 hours per day. The income of the participant is crucial to the family. Most of the family income of the participants (70 percent) were coming from the street food business. A total of 28 percent family income of the participants have come from this sector. A large number of participants (64 percent) have no alternative income source except street food business while 36 percent have another income source except street food vending. The data also highlighted that most of the respondents generate a profile in business because their total sale per day is higher than the total cost per day. 
Table 3: Successes Factors of Entrepreneurs of Street Food Sector

\begin{tabular}{llllll}
\hline & EFO & LSC & LPW & FEM & LCP \\
\hline Strongly Disagree & 2 & 0 & 0 & 0 & 0 \\
Disagree & 2 & 2 & 0 & 4 & 2 \\
Neural & 18 & 30 & 10 & 42 & 28 \\
Agree & 50 & 48 & 46 & 40 & 52 \\
Strongly Agree & 28 & 20 & 100 & 44 & 18 \\
Total (percentage) & 100 & 100 & 4.36 & 4.24 & 100 \\
Mean & 4.00 & 3.86 & .663 & .822 & 3.86 \\
Std. Deviation & .857 & .756 & & .729 \\
\hline
\end{tabular}

[Here, EFO = Easy Formation; LSC = Low Startup Cost; LPW = Less Paper Work, FEM = Few Employees, LCP $=$ Low Cost of Product]

Table 3 indicates different success factors of entrepreneurs of the street food sector with five different responses. The table shows that 78 percent of participants agreed that easy formation is a success factor while low startup cost is 68 percent. A total of 86 percent of participants were agreed that low startup cost as a success factor while a few employees were 84 percent. And 70 percent of respondents were agreed to the low cost of the product as a success factor. That means all of the success factors have a crucial impact over the business and initiative of the business of entrepreneurs of the street food sector. The table also shows that the mean of easy formation and low startup cost were 4.00 and 3.86 and standard deviation were .857 and .756 . The mean of less paperwork and few employees were 4.36 and .663 while the standard deviation is .663 and .822 . The mean and standard deviation of the low cost of the product is 3.86 and .729. The data indicated that less paperwork, few employees and easy formation are the main successes factors of entrepreneurs.

Table 4: Failure Factors of Entrepreneurs of Street Food Sector

\begin{tabular}{lllllllll}
\hline & ICA & ESRM & UNL & LBMS & HRB & LPU & LDI & HCS \\
\hline Strongly Disagree & 0 & 22 & 6 & 4 & 0 & 0 & 0 & 14 \\
Disagree & 16 & 32 & 8 & 14 & 14 & 0 & 4 & 24 \\
Neural & 24 & 24 & 38 & 30 & 18 & 14 & 14 & 20 \\
Agree & 38 & 18 & 34 & 40 & 52 & 36 & 50 & 40 \\
Strongly Agree & 22 & 4 & 14 & 12 & 26 & 50 & 32 & 2 \\
Total (Percentage) & 100 & 100 & 100 & 100 & 100 & 100 & 100 & 100 \\
Mean & 3.66 & 2.50 & 3.42 & 3.42 & 4.00 & 4.36 & 4.10 & 2.29 \\
Std. Deviation & 1.002 & 1.147 & 1.032 & 1.012 & .787 & .722 & .879 & 1.140 \\
\hline
\end{tabular}

[Here, ICA = Insufficient Capital; ESRM = Erratic Supply of Raw Material; UNL = Undefined Locations; LBMS

$=$ Lack of Business Management Skills; HRB = Harassment and Exploitation for Bribe; LPU = Lack of Public Utilities; LDI = Lack of Dignity; HCS = Hostile Customers $]$

The above Table 4 indicates the different failure factors of the entrepreneurs of the street food sector. The table shows that 60 percent of participants were agreed that insufficient capital is a failure factor. Erratic supply of raw material and hospital customers are not significant failure factors. A total of 48 percent of participants were agreed that undefined location is a failure factor. A large number of ( 52 percent) participant is agreed that lack of business management skills, harassment and exploitation of bribe (78 percent) and lack of public utilities (82 percent) are the crucial failure actors of the entrepreneurs. The mean and standard deviation of insufficient capital is 3.66 and 1.002. The mean of the erratic supply of raw materials and the undefined location was 2.50 and 3.42 while their standard deviation were 1.147 and 1.032. The mean of lack of business management skills and harassment and exploitation for bribe is 3.42 and 4.00 while the standard deviation is 1.012 and .787 . The mean of other factors such as lack of public utilities were 4.36, lack of dignity 4.10 and the hostile customer is 2.29 and the slandered deviation is $.722, .879$ and 1.140 respectively. Thus, the lack of public utility, harassment, and exploitation for the bribe are the crucial failure factors.

Table 5: Priority Ranking of Taking Policy to Assist Entrepreneurs

\begin{tabular}{|c|c|c|c|c|c|c|}
\hline \multirow[b]{2}{*}{ Policy to assist entrepreneurs } & \multicolumn{6}{|c|}{ Ranking } \\
\hline & 1 & 2 & 3 & 4 & 5 & 6 \\
\hline \multicolumn{7}{|l|}{ Provide SME loans to the entrepreneurs } \\
\hline \multicolumn{7}{|l|}{ Ensure the supply of quality raw material } \\
\hline \multicolumn{7}{|l|}{ Ensuring specific location/area for the business } \\
\hline \multicolumn{7}{|l|}{ Prevent the harassment regularity authority } \\
\hline \multicolumn{7}{|l|}{ Ensure public utility facilities } \\
\hline Recognize street food industry through legislation & & & & & & \\
\hline
\end{tabular}

According to the priority ranking, the entrepreneurs suggested their opinion to take an effective policy to improve their condition. Firstly, they said the government and local government should recognize their business 
through the legislation. The legislation will provide the shelter and sudden removal from their business location. The legislation also provides them the security of doing business. Secondly, the entrepreneurs stated that authority stops the harassment and exploitation of bribes. It is difficult for them to do business because of regular bribe. They said the government should take steps to prevent entrepreneurs from harassment and exploitation. Thirdly, the entrepreneurs stated that the specific location of the business is highly essential for them to do business. The authority often closes various locations for their business, thus they have faced enormous problems to find out a new place. Fourthly, they stated public utility such as electricity, water, etc. are essential for their business and the authority should provide the related utility facilities to them. Fifthly, the entrepreneurs demand SME loan with a low-interest rate. This will help them to start and expand their business. The present condition of the loan is not favorable for them. Lastly, the entrepreneurs stated that the supply of quality raw materials often difficult in Sylhet. The source of getting quality raw material is highly essential.

\section{Conclusion}

Though the street food sector in Sylhet faced numerous problems, this sector is going to increase over time. The entrepreneurs of this sector are young and not very educated. Thus, it is very difficult for them to manage startup capital while there is no opportunity to get a loan from any formal banking sector. The entrepreneurs also faced harassment and expositions from the government authority and local fanatic. They have a poor opportunity to get public utility service in the street such as gas, water, and electricity. The business management skills of the entrepreneurs are not good enough so they often failed to manage their business. To improve the current situation of this sector, it is essential to ensure SME loan for the entrepreneurs. The government can play a significant role to provide SME loan to the entrepreneurs. The bank and other financial institutions can play a significant role in this case. The entrepreneurs of Sylhet also face erratic raw material supply problem and this need to address properly. The wholesaler in Sylhet can play a crucial role in this case. The local government authority of Sylhet along with Sylhet City Corporation should ensure some specific locations for the entrepreneurs to set up their business. The authority should recognize the entrepreneurs through the law. The entrepreneurs have so many success factors such as easy formation, less paperwork, few employees, etc. Although entrepreneurs of this sector have so many failure factors the success factor exceeds the failure factors. As a result, the street food sector of Sylhet expands its area and more entrepreneurs are engaged in this sector.

\section{References}

Ahsan, S. E. (2012, November 18). Branding street foods. Retrieved January 2019, 11, from The Financial Express: http://print.thefinancialexpressbd.com/old/index.php?ref= MjBfMTFfMThfMTJfMV8x NTNfMTUwMjc1

Alauddin, S. M. (2015, July 31). Impact of technology on the street food vendors in Dhaka City. Retrieved January 2019, 25, from The Daily Sun: http://dailysun.com/printversion/details/62982/Impact-oftechnology-on-thestreet-food vendors-inDhaka-City

Allain, A. (1988). Street foods, the role and needs of consumers. Expert consultation on street foods. Jogjakarta, Indonesia: FAO.

Amin, A. T. (1989). Dhaka Past, Present, Future. Dhaka, Bangladesh: The Asiatic Society of Bangladesh

Bharan N. (2004). Employment and poverty alleviation. Ministry of Urban, Government of India

Bhowmik S.K. (2003). National Policy for Street Vendors. Economic and Political Weekly. 38(16): 1543-1546

Bhowmik, S. (2010). Street Vendors in the Global Urban Economy. Haryana: Sanat Printers.

Butale H.S. (2001). Urban Informal Sector Profile, Linkages and Constraints: A case of Francistown, Botswana. MSC Dissertation, University of Botswana

Chukuezi C.O. (2010). Entrepreneurs of the Streets: Socio-Economic Features of Street Food Vending in Owerri, Nigeria. European Journal of Social Sciences. 14(2): 183-188

Cohen, M. (1986). The Influence of the Street Food Trade on Women and Child Health. Advances in International Maternal and Child Health, 6.

Dardano, C. (2003). Caribbean regional working group on street food vendors. Retrieved from Report of FAO, PAHO and BNSI: fao.org/es/esn/food/carribean_report.pdf

Draper A. (1996). Street Foods in Developing Countries: The potential for micronutrient fortification. London School of Hygiene and Tropical Medicine Enterprises Development in Botswana

Harvie C. (2003). The Contribution of micro enterprises to economic recovery and poverty alleviation in East Africa. Faculty of Commerce-Economics Working Paper, University of Wollongong

Holya, A. v., \& Makhoanec, F. (2006). Improving street food vending in South Africa: Achievements and lessons learned. International Journal of Food Microbiology, 89-92.

Jimu I.M. (2004). An Exploration of street ending's contribution towards Botswana's Vision of Prosperity for all by 2016. Pula: Botswana Journal of African Studies. 18(1): 19-30

Joseph M.C (2011). The struggle to belong; dealing with diversity in 21st century urban settings. Paper presented at the International RC21 Conference, University of Johannesburg 
Linden E. (1993). The role of the informal sector. NEPRU Working Paper No.33, Windhoek, Namibia

Mitullah W.V. (2003) Street vending in African cities: A synthesis of empirical findings from Kenya, Cote D'ivoire, Ghana, Zimbabwe, Uganda and South Africa. WIEGO, Institute of Development Studies, University of Nairobi

Mokgosi K (1997). A study of informal trading in Gaborone, Thesis in the Faculty of Social Science, Department of Sociology, University of Botswana

Muinde O.K and E Kuria (2005) Hygienic and Sanitary practices of vendors of street foods in Nairobi, Kenya. African Journal of Food Agriculture and Nutritional Development. 5(1): 1-13

Muzaffar, A. T., Huq, I., \& Mallik, B. A. (2009). Entrepreneurs of the Streets: an Analytical Work on the Street Food Vendors of Dhaka City. International Journal of Business and Management, 4(2), 80-88.

Nasinyama, G. W. (1992). Study on street foods in Kampala, Uganda. Rome and Kampala: FAO and Makerere University

Ohiokpehai O. (2003). Nutritional Aspects of Street food in Botswana. Journal of Nutrition. 2(2): 76-81

Palmer, R. (2007) Skills for work? From skills development to decent livelihoods in Ghana's rural informal economy. International Journal of Educational Development 27. 397-420

Parker, J. C. (1996). Micro-and Small Scale Enterprises in Zambia: Results of the 1996 Nationwide Survey. London: Graham Bannock and Partners Ltd.

Somolekae G. (1992). Women in the informal sector and small scale enterprises: Some observations from a recent study in the informal sector and small enterprises development in Botswana. Proceedings of a National Seminar on the Informal Sector and small scale

Subratty, A., Beeharry, P., \& Sun, M. C. (2004). A survey of hygiene practices among food vendors in rural areas in Mauritius. Nutrition \& Food Science, 203 - 205.

Tinker, I., and M. Fruge. (1982). The street food project. Assignment Children. 57(58): 191-200

Tripp, A. M. (1997) Changing the rules: The politics of liberalization and the urban informal economy in Tanzania. University of California Press, Los Angels and London United Nations

Wickware, D. (1998). The Shadow Economy, Urban Age. The Global City Magazine, 6(1), 5-9.

\section{Notes}

Note 1. Tk. which is commonly known as BDT is the official currency of Bangladesh. 